\title{
明期終了時における遠赤色光照射の光強度および照射時間が スプレーギクの茎伸長に及ぼす影響
}

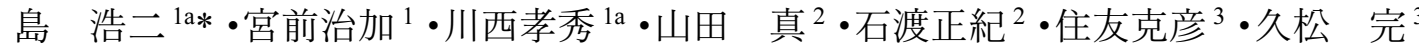 \\ 1 和歌山県農林水産総合技術センター農業試験場 640-0423 紀の川市貴志川町高尾 \\ 2 パナソニック電工株式会社 571-8686 門真市大字門真 \\ 3 農業・食品産業技術総合研究機構花き研究所 $305-8519$ つくば市藤本
}

\section{Effect of the Irradiance and Duration with Far-Red Light at the End of Day (EOD-FR) on Stem Elongation of Spray Type Chrysanthemum}

\author{
Kohji Shima $^{1 \mathrm{a} *}$, Haruka Miyamae ${ }^{1}$, Takahide Kawanishi ${ }^{1 \mathrm{a}}$, Makoto Yamada ${ }^{2}$, \\ Masaki Ishiwata ${ }^{2}$, Katsuhiko Sumitomo ${ }^{3}$ and Tamotsu Hisamatsu ${ }^{3}$ \\ ${ }^{1}$ Agricultural Experiment Station, Wakayama Research Center of Agriculture, Forestry and Fisheries, Kinokawa, Wakayama 640-0423 \\ ${ }^{2}$ Panasonic Electric Works Co., Ltd., Kadoma, Osaka 571-8686 \\ ${ }^{3}$ National Institute of Floricultural Science, Tsukuba, Ibaraki 305-8519
}

\begin{abstract}
The effect of irradiance and duration with far-red (FR) light at the end of the day (EOD-FR) on stem elongation of spray type chrysanthemum was investigated with two cultivars, 'Sei Prince' and 'Remidas' in order to reduce the growing period for cut flower production. When plants were exposed to FR light for one hour, stem elongation tended to shorten as irradiance decreased from 0.19 to $0.07 \mathrm{~W} \cdot \mathrm{m}^{-2}$. In 'Remidas' stem length under weak irradiance $\left(0.07 \mathrm{~W} \cdot \mathrm{m}^{-2}\right)$ was significantly shorter than that under strong irradiance $\left(0.19 \mathrm{~W} \cdot \mathrm{m}^{-2}\right)$. When plants were exposed to FR light under weak irradiance $\left(0.06 \mathrm{~W} \cdot \mathrm{m}^{-2}\right)$, stem elongation tended to be promoted as irradiation time increased from one hour to three hours. It is considered that stem elongation can be promoted under weak FR light irradiance conditions when irradiation time increased. In 'Sei Prince' and 'Remidas', stem elongation was promoted more than $15 \%$ on comparison between plants without treatment and plants exposed to FR light with $0.03 \mathrm{~W} \cdot \mathrm{m}^{-2}$, for two or three hours at the end of the day.
\end{abstract}

Key Words : flowering, photomorphogenesis, phytochrome

キーワード：フィトクローム，開花，光形態形成

\section{緒＼cjkstart言}

植物は，光を光合成におけるエネルギーとして利用する だけでなく，光形態形成のためのシグナルとして利用し， その生育制御に役立てている。これまでに，光環境が園芸 植物の茎伸長に影響を及ぼすとする報告は数多くあり，そ の中で赤色光（R 光）から遠赤色光（FR 光）を介したフィ トクローム反応がよく知られている， R/FR 比が小さい場 合，すなわち FR 光が多く含まれる光環境では，茎伸長反 応が促進される（Hisamatsu ら，2002; Khattak ら，2004; Li ら, 2000; McMahon ら, 1991; 村上ら, 1991; Rajapakse • Kelly,

2010 年 8 月 12 日 受付. 2010 年 11 月 17 日 受理.

本研究は，農林水産省「新たな農林水産政策を推進する実用技 術開発事業」に打いて行われた。

* Corresponding author. E-mail: shima_k0006@pref.wakayama.lg.jp a 現在: 和歌山県農林水産総合技術センタ一農業試験場暖地園芸 センター 644-0024 和歌山県御坊市塩屋町南塩屋
1992; Rajapakse ら，1993; 吉村ら，2002)。近年キクにおい ても, R/FR 比の小さい光環境に明期終了後の短時間遭遇さ せれば草丈が増加すること（Lund ら，2007），さらには明 期終了時から短時間に FR 光を照射（以下，EOD-FR）して も顕著な茎伸長促進効果が得られること（Hisamatsuら, 2008; 清水・久松，2007; 住友ら，2009）が示されている. キク生産では，定植後，長日条件下に拈いて栄養成長を維 持し，一定の草丈を確保した後に，短日条件下に移して開 花に至らせる。上述のような EOD-FR 処理により，短日条 件下での草丈伸長を促進することが可能になれば，草丈確 保のために必要な栄養成長期間の短縮が図られ，施設回転 率の向上につながることが期待できる

筆者らは，EOD-FR 処理によるスプレーギクの効率的な 茎伸長促進技術の開発に着手して扣り，温室での栽培条件 下に扣いて，明期終了時（日没後）から短時間の FR 光を 照射することで，茎伸長を容易に促進できること，また， その効果は暗期中断を行ら栄養成長期よりも短日条件での 
生殖成長期において高いことを明らかにした（島ら，2009）. しかしながら，施設栽培条件下に打いて茎伸長の促進に有 効な FR 光の光強度に関する知見は少なく, より効率的な 照射方法を明らかにするには, 光強度拈よび照射時間を含 めた処理方法を検討する必要がある. 特に, 実際の施設栽 培環境に扔いて EOD-FR 処理を実施するためには，顕著な 茎伸長の促進効果が得られる光強度の下限值を推察するこ とが望まれる。 そこで本研究では, 光強度ならびに照射時 間がスプレーギクの茎伸長に及ぼす影響を調査し，これら の効率的な照射方法の検討を行った。

\section{材料および方法}

各実験とも，材料にはスプレーギク ‘セイプリンス’ お よび'レミダス’を用いた，砂上げ育苗を行った発根苗を プランター（長さ $65 \mathrm{~cm} \times$ 幅 $25 \mathrm{~cm} \times$ 深さ $18 \mathrm{~cm}$ ) 飞 10 本 ずつ定植し，無摘心栽培とした. 1 処理区当たり 20 株を供 試した，培地にはピートモス：パーライト：鹿沼土：マサ 土を $5: 3: 1: 1$ の体積比で混合したものを用い, プランター 当たり $10 \mathrm{~L}$ を充填した. 肥料として, $\mathrm{N}: \mathrm{P}_{2} \mathrm{O}_{5}: \mathrm{K}_{2} \mathrm{O}$ を $14: 12: 14$ の割合で含んだ緩効性の被覆複合肥料を，株当 たり $1.5 \mathrm{~g}$ 与えた. 定植後, EOD-FR 処理開始までは 3 波長 型蛍光灯 (EFD25EL/22, 松下電工) による深夜 4 時間 (22:00 〜 2:00）の暗期中断を行い，その後， EOD-FR 処理を開始 した. EOD-FR 処理時の光源には, フィルタにより $600 \mathrm{~nm}$ 以下の光をカットした松下電工株式会社製の試作遠赤色光 蛍光灯 (第 1 図, R : 600-700 nm, FR : 700-800 nm の R/FR 比は放射照度で 0.06) を用いた。 また，照射時間の制御に は, 年間の日の出和よび日の入時刻がプログラミングされ， それらの時刻に応じて自動的に on/off の制御を行らタイム スイッチ（TB445101，松下電工）を用いた. 光強度の設定 時には，放射照度測定センサ（LP471RAD，デルタオーム） 扣よびデータロガー（HD2102.2，デルタオーム）を用いて 放射照度を測定し, その調整を行った。栽培は, 日最低気 温を $16^{\circ} \mathrm{C}$ 以上に維持したガラス温室内で行った。

\section{EOD-FR処理時の光強度が茎伸長に及ぼす影響 (実験1)}

2007 年 11 月 13 日に插し芽し, その発根苗を 11 月 27 日 にプランターへ定植した. 12 月 28 日に暗期中断を打ち切 るとともに, EOD-FR 処理を開始した. 光照射時間を日の 入り時刻から 1 時間とし, 照射時の光強度をプランター上 部で(1) $0.07 \mathrm{~W} \cdot \mathrm{m}^{-2}$, (2) $0.13 \mathrm{~W} \cdot \mathrm{m}^{-2}$, (3) $0.19 \mathrm{~W} \cdot \mathrm{m}^{-2}$ とな るように設定した。 また, 併せて FR 光照射を行わない (4)無処理区を設けた. EOD-FR 処理は 4 週間とし，処理終 了後の草丈拉よび節数について調査した.

\section{EOD-FR 処理時の照射時間が茎伸長に及ぼす影響 (実験 2)}

2008 年 9 月 18 日に插し芽し, 10 月 2 日に定植した. 10 月 24 日に暗期中断を打ち切るとともに, EOD-FR 処理を開 始した．照射時の光強度を $0.06 \mathrm{~W} \cdot \mathrm{m}^{-2}$ とし，照射時間を 日の入り時刻から (1) 1 時間, (2) 3 時間, (3) 5 時間とする区

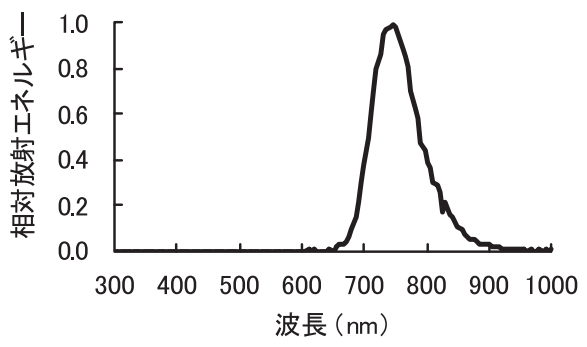

第 1 図 本実験に用いた遠赤色光光源の分光放射特性 エネルギーの最大值を 1.0 として表示

ならびに(4)無処理区を設けた. EOD-FR 処理は 4 週間と し，処理終了後の草丈および節数について調査した.

3. EOD-FR 処理時の照射時間と光強度が茎伸長に及ぼす 影響（実験 3)

2008 年 12 月 15 日に挿し芽し, 12 月 29 日に定植した. 2009 年 1 月 29 日に暗期中断を打ち切るとともに, FR 光照 射を開始した．照射時の光強度を $0.03 \mathrm{~W} \cdot \mathrm{m}^{-2}$ とし，照射 時間を(1) 1 時間，(2) 2 時間，(3) 3 時間，(4) 4 時間とする区 ならびに(5)光強度を $0.19 \mathrm{~W} ・ \mathrm{~m}^{-2}$ とし，照射時間を 1 時間 とする区を設定した．また，(6)無処理区を併せて設けた． EOD-FR 処理は開花に至るまで実施し, 処理 4 週間後の茎 の伸長量, 開花日ならびに切り花の形質について調査を 行った，施肥は基肥の他に，追肥として 2 月 9 日， 2 月 19 日拈よび 3 月 2 日に窒素濃度で $300 \mathrm{ppm}$ とした液肥を灌水 代わりに与えた.

\section{結 果}

\section{EOD-FR 処理時の光強度が茎伸長に及ぼす影響 (実験 1)}

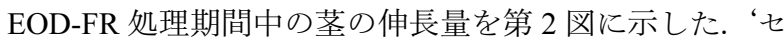
イプリンス’拉よび ‘レミダス’とも, EOD-FR 処理を行っ たすべての区に执いて，無処理区と比較して有意に伸長量 が増加した。“セイプリンス’では, EOD-FR 処理を実施し た場合の光強度にかかわらず茎伸長量は同等となり, 処理 区間に有意な差は認められなかった。一方，“レミダス’で は, EOD-FR 処理時の光強度が弱くなるにつれて茎伸長量 は小さくなる傾向にあり, $0.07 \mathrm{~W} \cdot \mathrm{m}^{-2}$ 区における茎伸長 量は $0.19 \mathrm{~W} \cdot \mathrm{m}^{-2}$ 区の $86 \%$ となり, 有意に小さくなった. また，処理終了時の節数は， $0.07 \mathrm{~W} \cdot \mathrm{m}^{-2}$ 区, $0.13 \mathrm{~W} \cdot \mathrm{m}^{-2}$ 区， $0.19 \mathrm{~W} ・ \mathrm{~m}^{-2}$ 区，無処理区の順に，“セイプリンス’ で は 38.5, 37.1, 37.1, 37.6, ‘レミダス’では 37.4, 36.6, 37.8, 36.5 であり，両品種とも処理区間に有意差は認められな かった.

\section{EOD-FR 処理時の照射時間が茎伸長に及ぼす影響 (実験 2)}

EOD-FR 処理期間中の茎の伸長量を第 3 図に示した。両 品種とも, EOD-FR 処理を行ったすべての区において, 無 処理区と比較して有意に伸長量が増加した。“セイプリン ス’では，EOD-FR 処理を実施したすべての区の茎伸長量 は同等となり，処理区間に有意な差は認められなかった。 

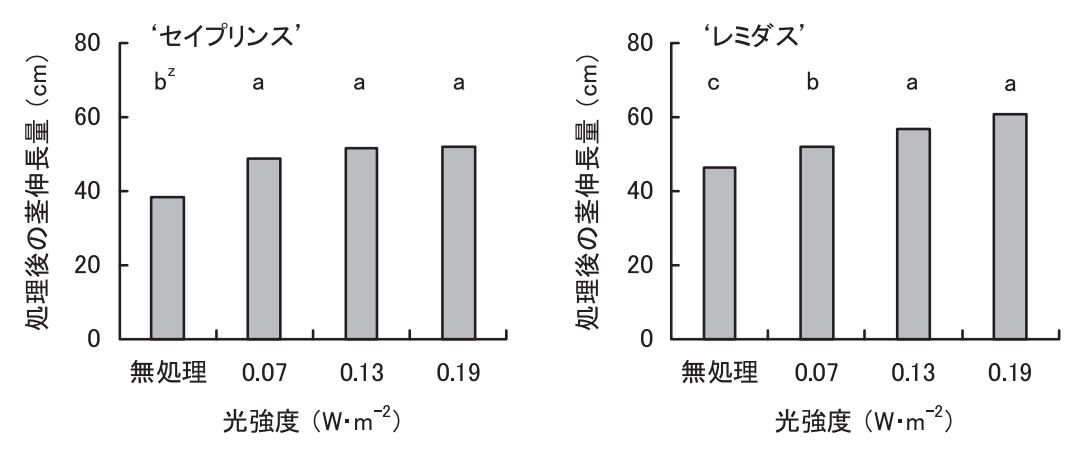

第 2 図 EOD-FR 処理時の光強度がスプレーギクの茎伸長に及ぼす影響（実験 1） 照射時間は 1 時間

${ }^{\mathrm{z}}$ 同一品種内の同じアルファベット文字間には, Tukey の検定により $5 \%$ レベルで有意差なし

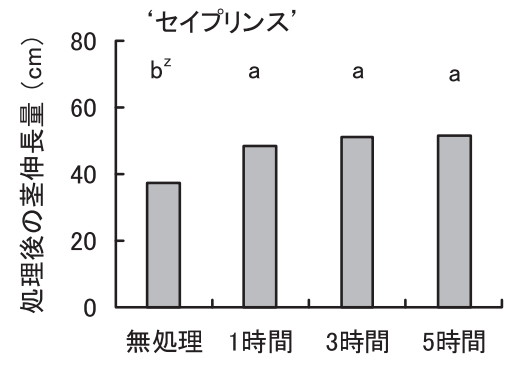

照射時間

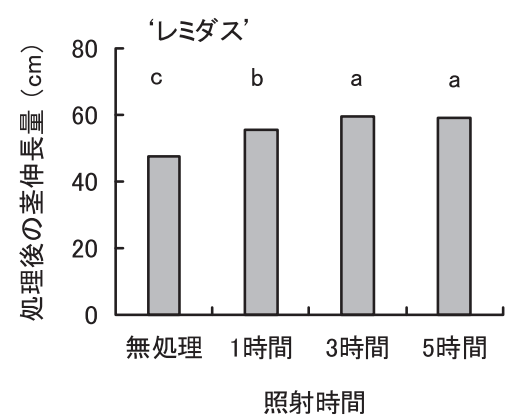

第 3 図 EOD-FR 処理時の照射時間がスプレーギクの茎伸長に及ぼす影響（実験 2) 放射照度は $0.06 \mathrm{~W} \cdot \mathrm{m}^{-2}$

$\mathrm{z}$ 同一品種内の同じアルファベット文字間には, Tukey の検定により $5 \%$ レベルで有意差なし

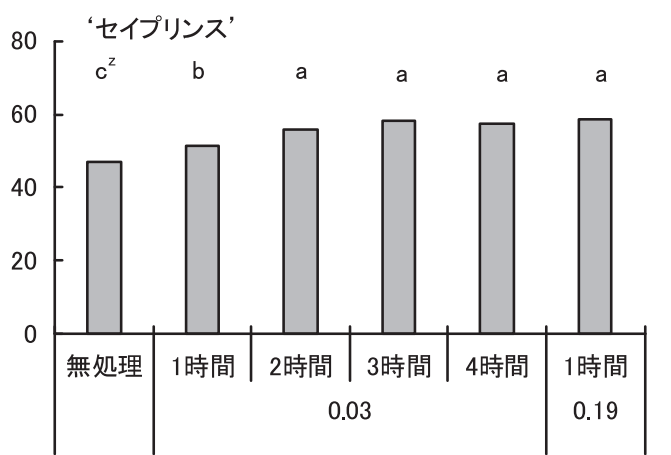

照射時間および光強度 $\left(W \cdot m^{-2}\right)$

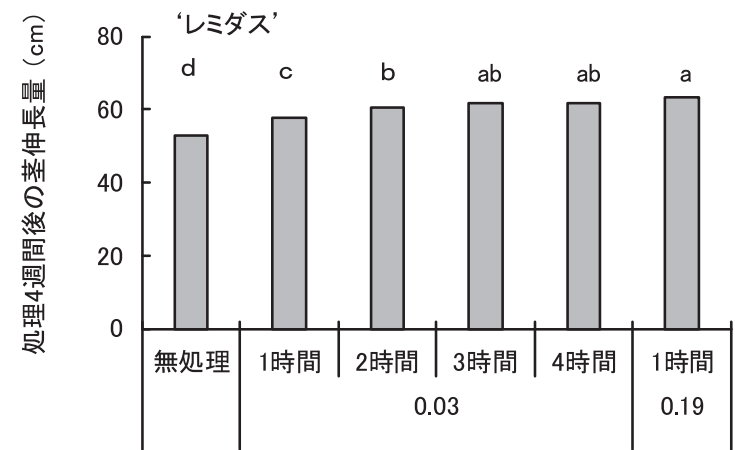

照射時間および光強度 $\left(W \cdot m^{-2}\right)$

第 4 図 EOD-FR 処理時の照射時間と光強度がスプレーギクの茎伸長に及ぼす影響（実験 3）

$\mathrm{z}$ 同一品種内の同じアルファベット文字間には, Tukey の検定により $5 \%$ レベルで有意差なし

一方，‘レミダス’では，照射時間を 3 または 5 時間とした 時の茎伸長量は, 1 時間の伸長量よりも大きくなった。 た，処理終了時の節数は，1 時間区，3 時間区， 5 時間区， 無処理区に損いて，“セイプリンス’ではそれぞれ 35.0, 35.0, 34.5, 35.4, ‘レミダス’では 37.0, 36.4, 36.6, 36.3 となり, 両品種とも処理区間に有意差は認められなかった.

3. EOD-FR 処理時の照射時間と光強度が茎伸長に及ぼす 影響（実験 3)

EOD-FR 処理 4 週間後の茎の伸長量を第 4 図に示した.
光強度が $0.03 \mathrm{~W} \cdot \mathrm{m}^{-2}$ の場合, 両品種とも照射時間が長く なるにつれて茥伸長は促進される傾向にあり，2 時間以上 の FR 照射を実施することで, 1 時間照射の時よりも茎伸長 量は有意に大きくなった。 ‘セイプリンス’では，光強度を $0.03 \mathrm{~W} \cdot \mathrm{m}^{-2}$ とし，2 時間以上の FR 照射を行った時の茎伸 長量は，光強度を $0.19 \mathrm{~W} ・ \mathrm{~m}^{-2}$ として 1 時間の照射を実施 した時のものと同等となった。 また, ‘レミダス’では, 強 度を $0.03 \mathrm{~W} \cdot \mathrm{m}^{-2}$ とし，3 時間以上の $\mathrm{FR}$ 照射を行った時の 茎伸長量が, 光強度 $0.19 \mathrm{~W} ・ \mathrm{~m}^{-2}$ で 1 時間の照射を行った 
第 1 表 EOD-FR 処理時の照射時間と光強度がスプレーギクの開花および切り花の形質に及ぼす影響（実験 3）

\begin{tabular}{|c|c|c|c|c|c|c|c|c|c|}
\hline $\begin{array}{l}\text { 品種 } \\
\text { 照射時間 }\end{array}$ & 光強度 & $\begin{array}{c}\text { 到花日数 } \mathrm{z} \\
\text { (日) }\end{array}$ & $\begin{array}{c}\text { 切り花長 } \\
(\mathrm{cm})\end{array}$ & $\begin{array}{c}\text { 切り花重 } \\
(\mathrm{g})\end{array}$ & $\begin{array}{l}\text { 節数 } \\
\text { (節) }\end{array}$ & $\begin{array}{l}\text { 茥径 } \\
(\mathrm{mm})\end{array}$ & 花序数 ${ }^{x}$ & 舌状花数 ${ }^{w}$ & 管状花数 ${ }^{w}$ \\
\hline \multicolumn{10}{|c|}{ セイプリンス } \\
\hline 無処理 & & $49 \mathrm{a}^{\mathrm{v}}$ & $83.5 \mathrm{c}$ & $71.3 \mathrm{a}$ & $41.3 \mathrm{a}$ & $5.2 \mathrm{a}$ & $11.1 \mathrm{a}$ & $19.2 \mathrm{a}$ & $150.0 \mathrm{a}$ \\
\hline 1 時間 & $0.03 \mathrm{w} \cdot \mathrm{m}^{-2}$ & $49 \mathrm{a}$ & $88.8 \mathrm{~b}$ & $67.4 \mathrm{a}$ & $41.0 \mathrm{a}$ & $5.0 \mathrm{a}$ & $10.4 \mathrm{a}$ & $19.7 \mathrm{a}$ & $155.9 \mathrm{a}$ \\
\hline 2 時間 & $0.03 \mathrm{w} \cdot \mathrm{m}^{-2}$ & $49 \mathrm{a}$ & $93.9 \mathrm{a}$ & $68.1 \mathrm{a}$ & $40.3 \mathrm{a}$ & $5.1 \mathrm{a}$ & $9.8 \mathrm{a}$ & $19.0 \mathrm{a}$ & $150.1 \mathrm{a}$ \\
\hline 3 時間 & $0.03 \mathrm{w} \cdot \mathrm{m}^{-2}$ & $49 \mathrm{a}$ & $98.2 \mathrm{a}$ & $67.5 \mathrm{a}$ & $41.4 \mathrm{a}$ & $5.1 \mathrm{a}$ & $10.1 \mathrm{a}$ & $19.3 \mathrm{a}$ & $151.0 \mathrm{a}$ \\
\hline 4 時間 & $0.03 \mathrm{w} \cdot \mathrm{m}^{-2}$ & $48 \mathrm{a}$ & $95.2 \mathrm{a}$ & $66.2 \mathrm{a}$ & $41.1 \mathrm{a}$ & $5.0 \mathrm{a}$ & $10.3 \mathrm{a}$ & $18.8 \mathrm{a}$ & $153.6 \mathrm{a}$ \\
\hline 1 時間 & $0.19 \mathrm{w} \cdot \mathrm{m}^{-2}$ & $50 \mathrm{a}$ & $96.6 \mathrm{a}$ & $70.7 \mathrm{a}$ & $41.0 \mathrm{a}$ & $5.1 \mathrm{a}$ & $10.3 \mathrm{a}$ & $19.5 \mathrm{a}$ & $157.6 \mathrm{a}$ \\
\hline \multicolumn{10}{|l|}{ レミダス } \\
\hline 無処理 & & $53 \mathrm{a}$ & $98.8 \mathrm{c}$ & $73.1 \mathrm{a}$ & $39.5 \mathrm{a}$ & $5.2 \mathrm{a}$ & $11.6 \mathrm{a}$ & $22.3 \mathrm{a}$ & $246.1 \mathrm{a}$ \\
\hline 1 時間 & $0.03 \mathrm{w} \cdot \mathrm{m}^{-2}$ & $52 \mathrm{a}$ & $103.3 \mathrm{~b}$ & $75.4 \mathrm{a}$ & $39.8 \mathrm{a}$ & $5.3 \mathrm{a}$ & $12.8 \mathrm{a}$ & $21.6 \mathrm{a}$ & $245.8 \mathrm{a}$ \\
\hline 2 時間 & $0.03 \mathrm{w} \cdot \mathrm{m}^{-2}$ & $51 \mathrm{a}$ & $104.3 \mathrm{~b}$ & $76.0 \mathrm{a}$ & $39.8 \mathrm{a}$ & $5.3 \mathrm{a}$ & $13.4 \mathrm{a}$ & $22.3 \mathrm{a}$ & $242.8 \mathrm{a}$ \\
\hline 3 時間 & $0.03 \mathrm{w} \cdot \mathrm{m}^{-2}$ & $52 \mathrm{a}$ & $108.3 \mathrm{a}$ & $73.9 \mathrm{a}$ & $39.5 \mathrm{a}$ & $5.0 \mathrm{a}$ & $11.8 \mathrm{a}$ & $23.0 \mathrm{a}$ & $262.7 \mathrm{~b}$ \\
\hline 4 時間 & $0.03 \mathrm{w} \cdot \mathrm{m}^{-2}$ & $52 \mathrm{a}$ & $107.9 \mathrm{a}$ & $74.5 \mathrm{a}$ & $40.4 \mathrm{a}$ & $5.0 \mathrm{a}$ & $12.1 \mathrm{a}$ & $23.0 \mathrm{a}$ & $241.3 \mathrm{a}$ \\
\hline 1 時間 & $0.19 \mathrm{w} \cdot \mathrm{m}^{-2}$ & $52 \mathrm{a}$ & $109.4 \mathrm{a}$ & $77.4 \mathrm{a}$ & $39.1 \mathrm{a}$ & $5.2 \mathrm{a}$ & $11.6 \mathrm{a}$ & $22.1 \mathrm{a}$ & $251.4 \mathrm{a}$ \\
\hline
\end{tabular}

${ }^{\mathrm{z}}$ 暗期中断打ち切り日からの日数

y下位から $25 \sim 26$ 節目の間

$\mathrm{x}$ 切り花時の舌状花に着色が認められた花序の数

${ }^{\mathrm{w}}$ 上位 3 花序に扣ける平均值

v 同一品種内の同じアルファベット文字間には, Tukey の検定により $5 \%$ レベルで有意差なし

ものと同等となった。

切り花長は, 光強度が $0.03 \mathrm{~W} \cdot \mathrm{m}^{-2}$ の場合には, 照射時 間が長くなるにつれて長くなる傾向にあり，“セイプリン ス’では 2 時間以上の FR 照射， ‘レミダス’では 3 時間以 上の FR 照射を行った時に, 光強度を $0.19 \mathrm{~W} ・ \mathrm{~m}^{-2}$ として 1 時間の照射を実施した時の切り花長と同等となった（第 1 表).また, 両品種とも切り花重, 節数扔よび茎径は, 処理 にかかわらず同等であった．到花日数は各区とも同様であ り，FR 光照射による開花の遅れは観察されなかった。 た, 舌状花数は両品種とも各区同等であった. 管状花数は, ‘セイプリンス’では各区とも同等であり, ‘レミダス’で は光強度 $0.03 \mathrm{~W} \cdot \mathrm{m}^{-2}$ で 3 時間照射を行った場合を除いて, 処理区間に差は認められなかった。 また, 花序数は両品種 とも処理にかかわらず同等であった。

\section{考察}

これまでに, FR 光照射と植物の応答反応との関係は多く の植物に扔いて調查されて扮り, FR 光照射がキクの茎伸長 を促進するとの報告も多い（Hisamatsu ら，2008; 清水・久 松，2007; 住友ら，2009）。しかしながら，これらの報告で 処理された光強度は, 地表面で $0.24 \mathrm{~W} ・ \mathrm{~m}^{-2}$ あるいは植物 体生長点付近で $10 \mathrm{~W} \cdot \mathrm{m}^{-2}$ と高いものであり, 実際の生産 現場に扒いて，このレベルの光強度の FR 光を照射するこ とは困難であると判断される。 また，これまでに茎伸長に 有効な光強度を明らかにしょらとした報告は見あたらな い，そこで，本研究では，光強度抒よび照射時間に関する 効率的な照射方法について検討を行った.

実験 1 飞打いて, FR 光の照射時間が 1 時間の場合, 光強 度が弱くなるにつれて茎の伸長程度が小さくなる傾向が認
められ, ‘レミダス’では $0.07 \mathrm{~W} ・ \mathrm{~m}^{-2}$ に和ける茎伸長量は $0.19 \mathrm{~W} \cdot \mathrm{m}^{-2}$ のものよりも有意に小さくなり，“セイプリン ス’でも $0.07 \mathrm{~W} \cdot \mathrm{m}^{-2}$ の伸長量は小さくなる傾向にあった. FR 光強度と茎の伸長程度の関係について, 吉村ら（2006） はストックに拈いて，光強度が弱くなると節間長が短く なったことを報告している，また，同様の反応を岸本ら （2009）もトルコギキョウに扔いて報告して打り，本実験の 結果と一致した，一方，実験 2 に打いては， $0.06 \mathrm{~W} ・ \mathrm{~m}^{-2}$ の弱い光強度でも，照射時間が長くなると茎の伸長程度が 大きくなる傾向が認められ，“レミダス’では照射時間が 3 時間の場合には 1 時間の場合よりも伸長量は増加した。佐 藤ら（2009）は，照射時間が長くなると茎の伸長が促進さ れることをトルコギキョウに沶いて報告している，これら のことから，光強度が弱くても照射時間を長くすることに より，茎伸長量を確保できるものと考觉られた，現段階で は, FR 光源は高価であることから, EOD-FR 処理の生産現 場への導入を図るためには，できるだけ少ない光源数での 処理が可能であることが望ましく，より弱い光強度におけ る照射方法の検討が必要と考兄られる。そこで，実験 3 に おいて, 顕著な茎伸長の促進効果が得られる光強度の下限 值を推察するため，光強度抏よび照射時間の関係から効率 的な処理方法の検討を行った．その結果， $0.03 \mathrm{~W} \cdot \mathrm{m}^{-2}$ の 弱い光強度に抢いても，照射時間を $2 \sim 3$ 時間とすること で十分な茎伸長を確保できた。

キクの茎伸長に関しては，EOD-FR 処理による促進効果 （清水・久松, 2007）ならびにこの効果に打けるフィトク ロームとジベレリンの関与（Hisamatsu ら，2008）が報告さ れている.これらのことから, 本実験で認められたスプレー ギクの草丈の伸長促進についても，フィトクロームを介し 
た伸長反応に基づいた現象であると推察される. EOD-FR 処理による伸長促進は, フィトクローム分子種のらち, 光 の明暗に左右されず安定的に存在する phyB タイプを介し た反応であり, 典型的な R/FR 可逆反応を示す（Hisamatsu ら，2005).フィトクローム反応は, その反応に必要な光量 によって区別され, 超低光量反応, 低光量反応, 高照射反 応の 3 つに分かれる. このらち, 低光量反応は典型的な R/ FR 可逆反応を示すことから, EOD-FR 処理による茥伸長は 低光量反応に相当すると考えられており, この反応では相 反則が成り立つ（篠村，2001）。 すなわち, 反応程度は, 光 強度と照射時間の 2 つ要因によって決定され, 光受容体 で捕獲した光エネルギーの総量と相関がみられる. 本研究 に抢いても, 強い光 $\left(0.19 \mathrm{~W} \cdot \mathrm{m}^{-2}\right)$ のもとでは短時間（1 時間）の照射によっても十分な伸長効果が認められ, 弱い 光 $\left(0.03 \mathrm{~W} \cdot \mathrm{m}^{-2}\right)$ のもとではより長い時間（2３時間） の照射が必要であった. このことから, 本研究に打ける光 強度と照射時間の関係も, 相反則に属するものと推察され る. 一方, 実験 1 の ‘セイプリンス’ に打いて, 光強度が 一定以上に強くなった場合や，実験 2 に拈いて照射時間が 3 時間から 5 時間に長くなった場合，あるいは実験 3 にお いて照射時間が 3 時間から 4 時間に長くなった場合には, 茥の伸長量に差は認められなかった。 また，筆者らは別の 実験に打いて, 光強度 $0.19 \mathrm{~W} \cdot \mathrm{m}^{-2}$ の $\mathrm{FR}$ 光を 1 時間以上 照射しても茥伸長量に差がないことを観察している（デー タ略).フィトクロームは, 上述のように光可逆性を示し, $\mathrm{R} / \mathrm{FR}$ 比の光環境条件に応じて $\mathrm{R}$ 光吸収型 (Pr 型) と FR 光 吸収型 (Pfr 型) の 2 つ吸収タイプによる光平衡状態が保 たれる. 光変換を飽和させる量の FR 光が照射されると, Pfr 型のほとんどはPr 型に変換された状態で光平衡状態に 達し，Pr 型とPfr 型の割合は97\%と3\%になるとされてい る (Silverthorne, 2004). このため, 本研究に打いても, 一 定以上に FR 光の光強度が強くなった場合や照射時間が長 くなった場合には, フィトクロームは Pr 型が大部分を占有 する光平衡状態に達し, それ以降の茎伸長の促進作用は得 られなかったものと推察される.

キクでは, FR 光を長時間照射すると花成が抑制されるこ と（Cathey・Borthwick, 1964; 吉村・金浜，2000）が報告さ れている. また，島ら（2009）も，FR光を深夜に照射した 場合には花序数が減少する傾向を観察している。このよう に，照射時間が長くなると開花に悪影響を及ぼすことも懸 念される. しかしながら, 実験 3 に打いて実施した切り花 調査の結果, FR 光を $3 \sim 4$ 時間照射した場合に扣いても開 花遅延や花序数の減少傾向は認められなかった。林ら （2008）は，ヒマワリに拈いて EOD-FR 処理を行った場合 には，舌状花および管状花が減少することを報告している が，本実験で EOD-FR 処理を行った場合の舌状花数や管状 花数は無処理と同等以上であり, 品質の低下は認められな かった. また, EOD-FR 処理を行った切り花の切り花重, 節数および茎径は, 無処理のものと同等であり, 切り花品
質に悪影響を及ぼすことはなかった。 これらのことから， 本研究で実施した EOD-FR 処理の範囲内では, 切り花長以 外の切り花品質や開花に影響を及ぼさず，効率的に茥伸長 を促進できるものと考えられた。

以上の結果から, スプレーギクの EOD-FR処理において, 光強度が弱い場合にも 3 時間程度まで照射時間を長くとる ことで，十分な茎伸長量を確保できることが明らかとなっ た. これにより，少ない光源数のもとでも EOD-FR 処理が 可能になることが示唆され, 光源設置時に必要なイニシャ ルコストの低減につながることが期待できる，本研究にお いて使用した FR 光源ならびに環境条件下では, ‘セイプリ ンス’で $0.03 \mathrm{~W} \cdot \mathrm{m}^{-2}$ で日没後 2 時間, 同様に ‘レミダス’ で 3 時間の照射において十分な伸長効果が認められた。な お，本 FR 光源に打ける放射照度を光量子束密度に換算し た場合, $0.03 \mathrm{~W} \cdot \mathrm{m}^{-2}$ の放射照度は約 $0.2 \mu \mathrm{mol} \cdot \mathrm{m}^{-2} \cdot \mathrm{s}^{-1}$ の 光量子束密度に相当する. スプレーギクの EOD-FR 処理に 打いて, これらの光強度执よび照射時間が効率的な茥伸長 効果を得られる目安となると考えられるが，品種による EOD-FR 処理に対する反応の違いが存在することが推察さ れることから, 今後, より多くの品種で本研究において得 られた処理方法の適応性を検証する必要があろう。

\section{摘 要}

スプレーギク生産における栽培期間の短縮を図るため, 明期終了時の遠赤色光照射（EOD-FR）に打ける光強度抒 よび照射時間が茎伸長促進に及ぼす影響を“セイプリンス’ および ‘レミダス’を用いて調査した，照射時間を 1 時間， 光強度を $0.07 \sim 0.19 \mathrm{~W} \cdot \mathrm{m}^{-2}$ とした場合，光強度が弱くな るにつれて茥伸長量が劣る傾向にあり，“レミダス’では $0.07 \mathrm{~W} \cdot \mathrm{m}^{-2}$ の茎伸長量は $0.19 \mathrm{~W} \cdot \mathrm{m}^{-2}$ よりも有意に小さ くなった。一方, 光強度が $0.06 \mathrm{~W} \cdot \mathrm{m}^{-2}$ の場合にも, 照射 時間を 1 時間から 3 時間に延長すると茎伸長量が増加し, 光強度が弱い場合にも照射時間を長くとることで，十分な スプレーギクの茎伸長量を確保できることが確認された. ただし，照射時間が 3 時間と 5 時間の場合の茎伸長量に差 は認められなかった. スプレーギクの茎伸長促進のための 効率的な EOD-FR 処理方法として，“セイプリンス’では $0.03 \mathrm{~W} \cdot \mathrm{m}^{-2}$ で 2 時間, 同様に ‘レミダス’では 3 時間の FR 光を照射することで，無処理と比較して $15 \%$ 以上の茥 伸長の促進が認められた.

\section{引用文献}

Cathey, H. M. and H. A. Borthwick. 1964. Significance of dark reversion of phytochrome in flowering of Chrysanthemum morifolium. Bot. Gaz. 125: 232-236.

林 孝洋・西川久仁子・矢澤 進. 2008. 明期終了時の赤 色・遠赤色蛍光灯補光がヒマワリの開花と花序の構成 に及ぼす影響. 園学研. 7 (別 1): 223.

Hisamatsu, T., N. Oyama-Okubo, K. Ichimura, S. Esaki, R. Oi 
and M. Koshioka. 2002. Interactions of red and far-red light modification with temperature on shoot extension and flowering in stock (Matthiola incana (L.) R. Br.). J. Hort. Sci. Biotech. 77: 1-8.

Hisamatsu, T., K. Sumitomo and H. Shimizu. 2008. End-of-day far-red treatment enhances responsiveness to gibberellin and promotes stem extension in chrysanthemum. J. Hort. Sci. Biotech. 83: 695-700.

Hisamatsu, T., R. W. King, C. A. Helliwell and M. Koshioka. 2005. The involvement of gibberellin 20-oxidase genes in phytochrome-regulated petiole elongation of Arabidopsis. Plant Physiol. 138: 1106-1116.

Khattak, A. M., S. Pearson and C. B. Johnson. 2004. The effects of far red spectral filters and plant density on the growth and development of chrysanthemums. Sci. Hortic. 102: 335-341.

岸本真幸 - 前田香那子 - 加藤正浩 - 山田 真 - 石渡正紀 • 住友克彦・久松 完. 2009. 短時間遠赤色光照射の照 射時間帯と光強度がトルコギキョウの生育に及ぼす影 響. 園学研. 8 (別 2): 337.

Li, S., N. C. Rajapakse, R. E. Young and R. Oi. 2000. Growth responses of chrysanthemum and bell pepper transplants to photoselective plastic films. Sci. Hortic. 84: 215-225.

Lund, J. B., T. J. Blom and J. M. Aaslyng. 2007. End of day lighting with different red/far-red ratios using light-emitting diodes affects plant growth of Chrysanthemum $\times$ morifoliumu Ramat. 'Coral Charm'. HortScience. 42: 1609-1611.

McMahon, M. J., J. W. Kelly and D. R. Decoteau. 1991. Growth of Dendranthema $\times$ grandiflorum (Ramat.) Kitamura under various spectral filters. J. Amer. Soc. Hort. Sci. 116: 950954.

村上克介 - 洞口公俊 - 森田政明 - 相賀一郎. 1991. 遠赤色 光付加照射によるヒマワリ幼植物の伸長成長制御. 生 環調. 29: 73-79.

Rajapakse, N. C. and J. W. Kelly. 1992. Regulation of chrysanthemum growth by spectral filters. J. Amer. Soc. Hort. Sci. 117: 481-485.
Rajapakse, N. C., M. J. McMahon and J. W. Kelly. 1993. End of day far-red light reverses height reduction of chrysanthemum induced by $\mathrm{CuSO}_{4}$ spectral filters. Sci. Hortic. 53: 249-259.

佐藤武義・工藤則子・森山厳與・大川秀樹・金山喜則・金 浜耕基. 2009. トルコギキョウの秋冬出し作型におけ る遠赤色光電球形蛍光ランプを利用した日長延長によ る開花促進. 園学研. 8: 327-334.

篠村和子. 2001. フィトクロムファミリーとその生理機能 分担. p. 39-45. 和田正三・徳富 哲・長谷あきら・長 谷部光泰編著. 細胞工学別冊植物細胞工学シリーズ. 16 植物の光センシング一光情報の受容とシグナル伝 達一. 秀潤社. 東京.

島 浩二・川西孝秀・山田 真・石渡正紀・住友克彦・久 松 完. 2009. 明期終了時の短時間遠赤色光照射が冬 季に打けるスプレーギクの茥伸長に及ぼす影響. 園学 研. 8: 335-340.

清水 浩・久松 完. 2007. 画像計測システムを用いた明 期終了時の短時間遠赤色光光照射によるキクの伸長成 長解析. 植物環境工学. 19: 203-207.

Silverthorne, J. 2004. フィトクロムと光による植物の発生制 御. p. 381-408. Taiz, L. ・ E. Zeiger 編. 植物生理学第3 版. 培風館. 東京.

住友克彦・山形敦子・島 浩二・岸本真幸・久松 完. 2009 . 数種切り花類の開花および茎伸長に及ぼす明期終了時 の短時間遠赤色光照射 (EOD-FR) の影響. 花き研報. 9: $1-11$.

吉村正久 - 金浜耕基. 2000. 赤色光 / 遠赤色光光量子束 比が切り花品質と開花に及ぼす影響. 園学雑. 69 (別 1): 136.

吉村正久・西山 学・金浜耕基. 2002. ストックの主枝の 生長と開花に及ぼす赤色光または遠赤色光と赤色光／ 遠赤色光の影響. 園学雑. 71: 575-582.

吉村正久・佐々木 厚・森山厳與・柴原雄右・勝田敬子・ 金浜耕基. 2006. ストックの開花に及ぼす夜間照射用 各種光源の種類と光量の影響. 園学研. 5: 297-301. 